\title{
Keanekaragaman Makrozoobentos sebagai Indikator Kualitas Air Sungai Cisadane, Jawa Barat - Banten (Macrozoobenthos diversity as indicator of water quality of Cisadane River)
}

\author{
Ratna Siahaan ${ }^{1)^{*}}$, Andry Indrawan ${ }^{2)}$, Dedi Soedharma ${ }^{2)}$, Lilik B.Prasetyo ${ }^{2)}$ \\ 1) Jurusan Biologi Fakultas MIPA Universitas Sam Ratulangi Manado \\ ${ }^{2}$ Sekolah Pasca Sarjana Institut Pertanian Bogor \\ E-mail korespondensi: ratna245_siahaan@yahoo.com
}

Diterima 10 Januari 2012, diterima untuk dipublikasikan 23 Januari 2012

\begin{abstract}
Abstrak
Sungai Cisadane memiliki multifungsi untuk kebutuhan pertanian, rumah tangga dan industri. Namun, kegiatan manusia di Daerah Aliran Sungai/DAS Cisadane dan di Sungai Cisadane dapat mengancam fungsi dan nilai ekosistem S.Cisadane. Penelitian ini bertujuan untuk menganalisis keanakeragaman makrozoobentos sebagai indikator kualitas air S.Cisadane. Penelitian dilakukan di sembilan (9) titik di sepanjang Sungai Cisadane dari hulu hingga hilir. Sampel makrozoobentos dikoleksi dengan jala surber dan Eckman Grabb. Pada musim kemarau, kekayaan taksa makrozoobentos terendah di bagian tengah dan hilir hilir (8 taksa) dan tertinggi di hulu (20 taksa). Kualitas air sungai ditentukan berdasarkan Indeks keanekaragaman Shannon-Wiener $\left(H^{\prime}\right)$. Kualitas air S.Cisadane yaitu baik/tercemar sangat ringan di hulu (Stasiun 1), cukup baik/tercemar ringan di hulu - tengah (Stasiun 2-5), sedang/tercemar sedang tengah mendekati hilir (Stasiun 6), dan buruk/tercemar berat di hilir (Stasiun 7-9). Kata kunci: kualitas air, makrozoobentos, Sungai Cisadane
\end{abstract}

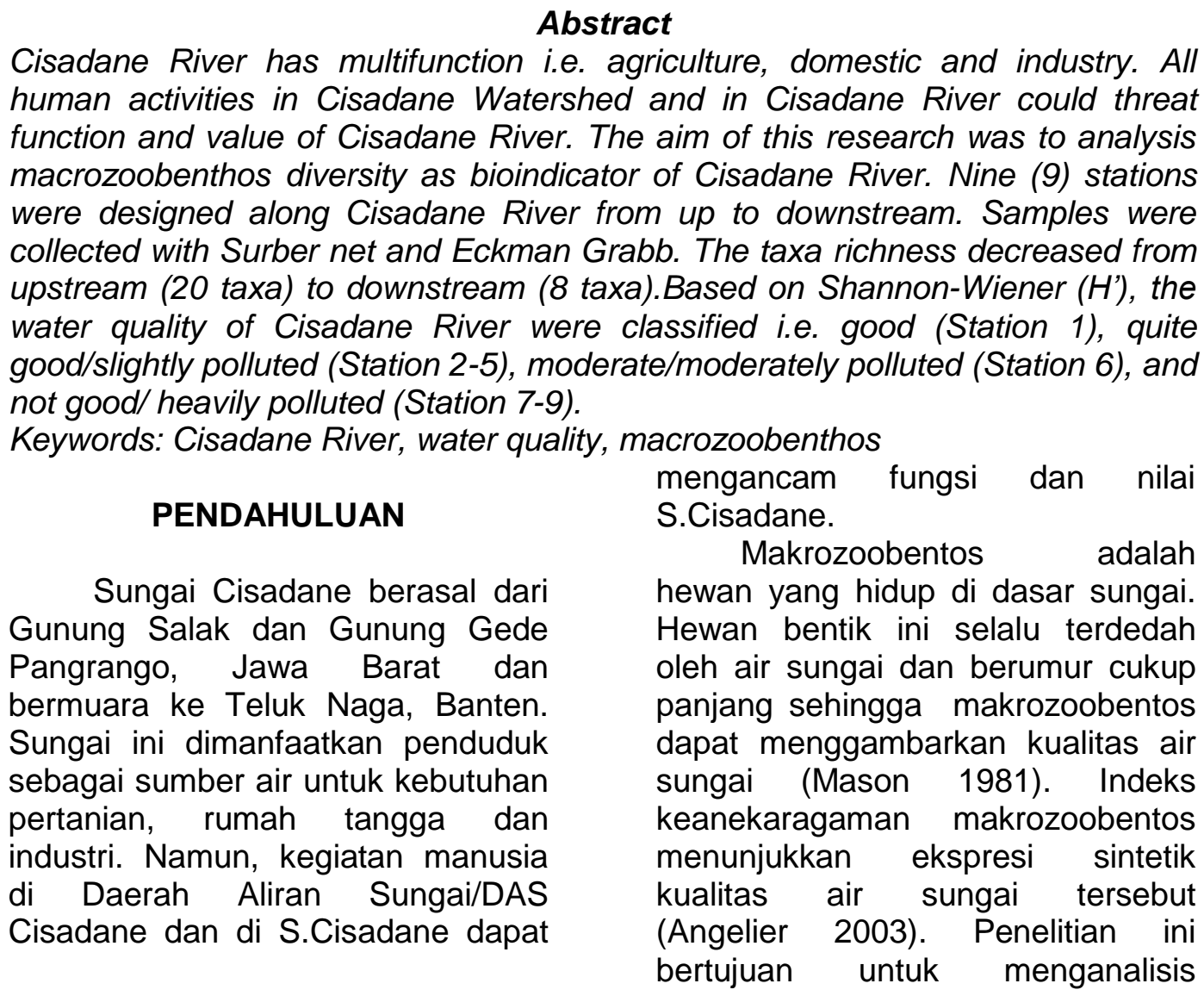


keanekaragaman makrozoobentos sebagai indikator kualitas air S.Cisadane.

\section{METODE}

\section{Tempat dan Waktu}

Penelitian dilakukan di sembilan (9) titik di sepanjang Sungai Cisadane dari hulu hingga hilir yang melintasi Provinsi Jawa Barat dan Banten pada Agustus November 2011. Tiga (3) stasiun ditempatkan di tiap bagian/segmen sungai (Gambar 1).

\section{Pengambilan dan Identifikasi Makrozoobentos \\ Sampel makrozoobentos} dikoleksi dengan jala surber $(30 \times 30$ $\mathrm{cm})$ untuk substrat batuan dan Eckman Grabb $(25 \times 25 \mathrm{~cm})$ untuk substrat berlumpur (Fachrul 2007). Sampel diambil satu kali untuk tiap bulan. Pengambilan sampel dilakukan secara komposit. Sampel lalu disaring, diawetkan, diberikan reagen Rose Bengal $1 \%$, diindentifikasi dan difoto di Laboratorium Biomikro 1, Departemen Manajemen dan
Sumberdaya Perikanan, IPB. Sampel didentifikasi dengan menggunakan buku acuan Jutting (1953 dan 1956), Pennak (1953).

\section{Analisis Data}

Kualitas air sungai ditentukan berdasarkan keanekaragaman makrozoobentos. Indeks keanekaragaman yang digunakan yaitu Indeks Shannon-Wiener (H') (Magurran 1991). Kepadatan makrozoobentos diketahui dari rumus Odum (1971). Indeks Keanekaragaman Shannon-Wiener $\left(\mathrm{H}^{\prime}\right)$ digunakan untuk menentukan tingkat pencemaran seperti S.Cisadane. Staub et al. (1970) yang dikutip Wilhm (1975) membagi tingkat pencemaran berdasarkan nilai indeks $\mathrm{H}^{\prime}$ ke dalam empat tingkat yaitu: $H^{\prime}=3,0-4,5$ : tercemar sangat ringan; $H^{\prime}=2,0-$ 3,0 : tercemar ringan; $H^{\prime}=1,0-2,0$ : tercemar sedang; $\quad H^{\prime}=$ $0,0-1,0$ : tercemar berat

\section{HASIL DAN PEMBAHASAN}

Pencemaran yang masuk ke sungai dapat mengganggu keseimbangan makrozoobentos.

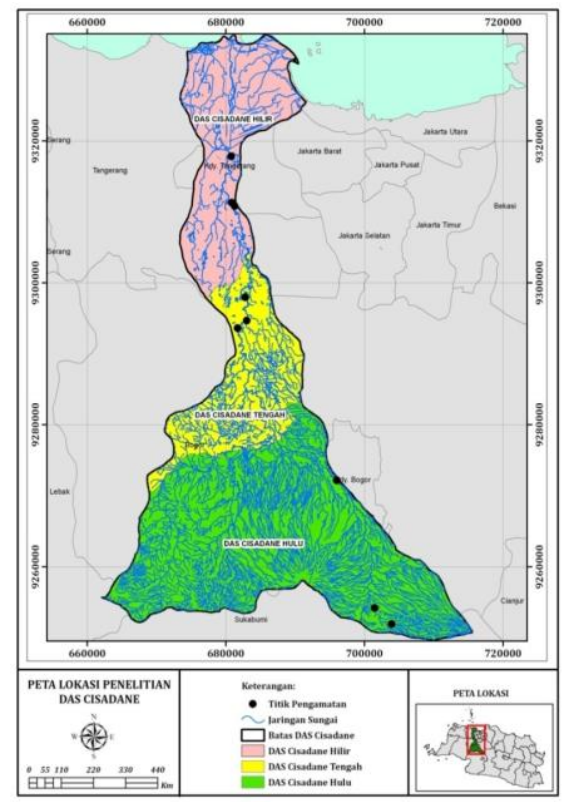

Gambar 1. Lokasi Penelitian

Sungai yang tidak tercemar atau sungai sehat menurut Roback
(1974) adalah sungai yang mendukung kehidupan organisma 
akuatik dengan semua tingkat trofik terwakilkan secara proporsional dan tidak ada ketidakseimbangan populasi. Dengan kata lain, sungai yang berkualitas baik akan memiliki keanekaragaman makrozoobentos yang tinggi dan tidak ditemukan taksa yang memiliki kepadatan yang tinggi.

Berdasarkan hal ini, kualitas air S.Cisadane semakin memburuk ke arah hilir pada musim kemarau. Indeks H' menurun dengan cukup tajam dan kekayaan taksa (S) juga menurun namun kepadatan individu cenderung meningkat (Tabel 1). Pencemaran telah menyebabkan hanya taksa tertentu saja yang dapat hidup di bagian sungai tersebut. Ini ditunjukkan oleh peningkatan individu-invidu dari taksa tertentu (Gambar 2a). Kekayaan taksa (S') makrozoobentos semakin ke hilir juga semakin menurun (Gambar 2b). Kekayaan taksa paling tinggi di Stasiun $2(S=20)$ yang berada di hulu dan yang paling rendah di Stasiun 6 dan $7(S=8)$ yang berada di bagian tengah dan hilir. Peningkatan individu dari taksa tertentu, secara umum, akan diiringi dengan penurunan kekayaan taksa di tempat tersebut.

Indeks H' pada musim hujan berfluktuasi namun cenderung menurun ke hilir. Indeks $H^{\prime}$ pada

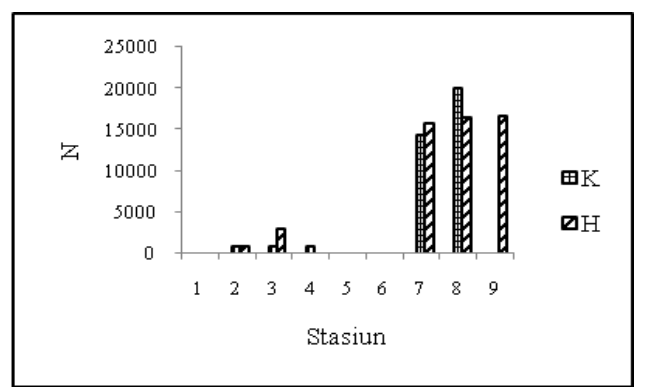

a.Kepadatan (individu/m2)

Gambar 2. Kepadatan dan kekayaan taksa makrozoobentos S.Cisadane Keterangan: K:musim kemarau; $\mathrm{H}$ : musim hujan
Stasiun 4 dan 6 sangat rendah $\left(H^{\prime}=0\right)$, hanya ada satu jenis makrozoobentos yang ditemukan. Kekayaan jenis yang sangat rendah $(\mathrm{S}=1)$ mungkin disebabkan saat pengambilan telah turun hujan sangat deras di bagian hulu anakanak sungai. Kecepatan arus yang sangat tinggi dapat menghayutkan makrozoobentos yang tidak melekat kuat di batuan. Hanya Melanoides sp. yang ditemukan di lokasi ini. Gastropoda ini hidup melekat di batuan. Pada lokasi ini, air sungai tampak sangat keruh.

Taksa yang ditemukan melimpah di Stasiun 7-9 merupakan makrozoobentos dari Ordo Gastropoda dan Oligochaeta. Kekayaan taksa sangat miskin di ketiga stasiun yang terletak dibagian hilir. Air sungai tampak keruh dan kecepatan arus lambat. Konsentrasi oksigen terlarut/DO yang rendah dan air yang tidak segar atau "septik" seringkali membatasi organisma hidup (Harman 1974). Anggota Gastropoda yang melimpah hanya 1 atau 2 jenis yaitu Melanoides sp. dan Thiara sp. (Gambar 3). Harman (1974) menduga penurunan kekayaan taksa hingga hanya ada 1 atau 2 jenis dari Gastropoda disebabkan telah terjadi pencemaran organik.

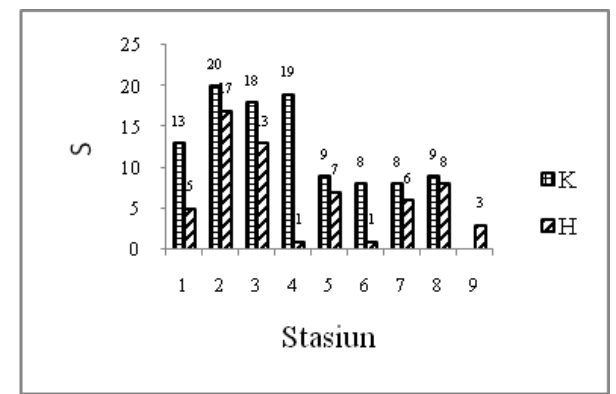

b. Kekayaan taksa (S) 


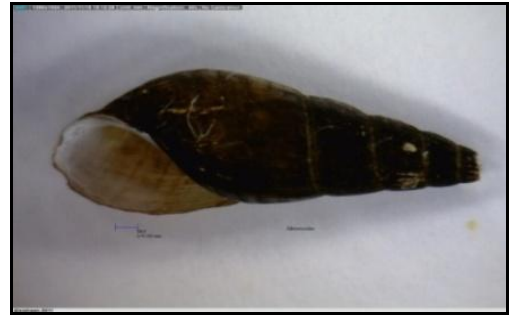

a.Melanoides sp.

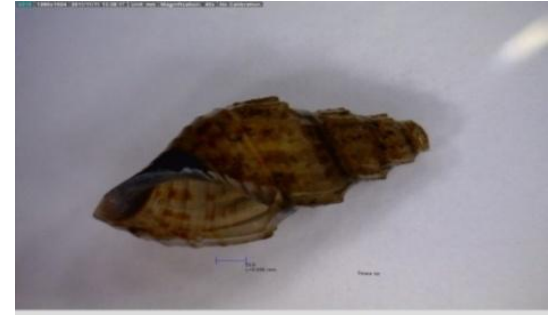

b. Thiara

Gambar 3. Makrozoobentos dari Taksa Gastropoda di S.Cisadane

Larva Ephemenoptera hanya ditemukan di Stasiun 1-5. Taksa ini tidak ditemukan di stasiun menuju hilir. Menurut Roback (1974), larva Ephemenoptera kurang sensitif/peka terhadap pencemaran organik. Walaupun demikian, bahan organik yang tinggi akan menjadi faktor pembatas. Jenis yang banyak ditemukan yaitu Baetis sp (Gambar 4a) dan Paraleptophlebia sp (Gambar 4b).

Diptera adalah ordo terbesar dari Insecta yang menghuni perairan tawar (Covich et al. 1999) sehingga larva Diptera mudah ditemukan di S.Cisadane terutama di Stasiun 1-5. Larva terbesar dari Diptera yaitu larva Chironomidae (Sudarso 2002). Larva Chironomidae seperti Polypedilum sp (Gambar 5a) banyak ditemukan di Stasiun 1-5. Larva Tanytarsus sp (Gambar 5b) hanya ditemukan di Stasiun 1-2.

Larva Chironomidae telah digunakan sebagai bioindikator kualitas air sungai untuk menentukan tingkat pencemaran akibat pencemaran organik.

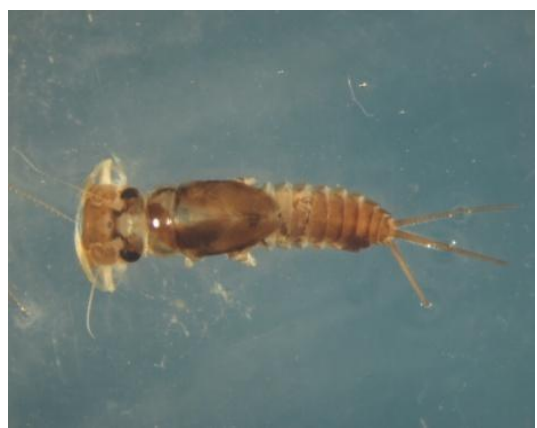

b. Paraleptophlebia sp

a. Baetis sp

Gambar 4. Makrozoobentos dari Taksa Ephemenoptera di S.Cisadane

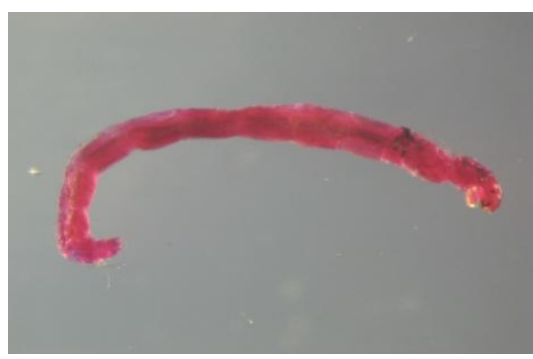

a. Polypedilum sp

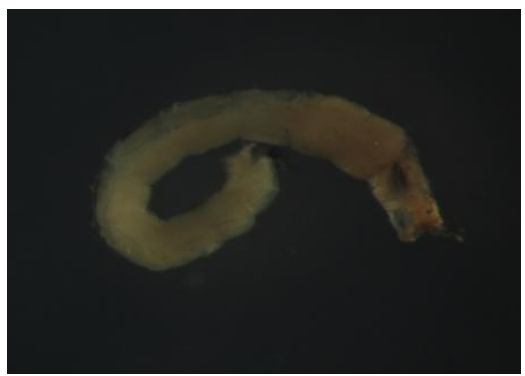

b. Tanytarsus sp

Gambar 5. Makrozoobentos dari Taksa Diptera di S.Cisadane 
Chironomidae akan melimpah di air sungai dengan pencemaran sedang. Namun, larva Chironomidae akan menurun jika pencemaran meningkat menjadi pencemaran berat (Sudarso 2002). Roback (1974) juga mengatakan larva Chiromidae biasanya toleran terhadap pencemaran organik. Beberapa larva Chironomidae memiliki $\mathrm{Hb}$ (haemoglobin) dalam darahnya yang memungkinkan mereka dapat hidup di sungai dengan konsentrasi oksigen terlarut cukup rendah.

Kehadiran larva Diptera khususnya Chironomidae menunjukkan telah terjadi pencemaran organik di S.Cisadane mulai dari hulu hingga hilir. Ketidakhadiran Larva Diptera di stasiun lain diduga akibat pencemaran bahan toksik. Larva Chironomidae dilaporkan tidak tahan atau sensitif terhadap bahan-bahan toksik seperti logam berat dan pestisida. Larva Insecta hanya ditemukan di Stasiun 1-5 yang mendekati hulu. Larva tidak ditemukan di stasiun mendekati hilir. Larva insecta umumnya dapat hidup di air yang telah tercemar organik namun tidak dapat hidup di air sungai yang tercemar bahan toksik. Misalnya, menurut Roback (1974), Trichoptera toleran terhadap pencemaran organik tapi sensitif terhadap pencemar toksik.

Lintah air tawar (Hirudinea) yang ditemukan di S.Cisadane ada 2 jenis yaitu Helobdella sp. (Gambar 6a) dan Glossiphonia sp. (Gambar 6b). Sawyer (1974) mengatakan bahwa lintah merupakan makrozoobentos yang melimpah di perairan kaya bahan organik. Hal yang wajar jika lintah ini ditemukan melimpah di Stasiun 3-6. Walaupun demikian, mereka tidak ditemukan Stasiun 1-2 meskipun kedua stasiun ini telah tercemar bahan organik. Hal ini mungkin disebabkan lintah lebih menyukai kecepatan air sungai yang cukup lambat dan dangkal (Sawyer 1974). Kecepatan arus sungai di kedua stasiun ini paling tinggi sebab berada di di bagian paling hulu. Lintah juga tidak ditemukan di Stasiun 7-9. Hal ini mungkin disebabkan adanya pencemaran bahan toksik di stasiun tersebut. Menurut Sawyer (1974), lintah tidak ditemukan di air sungai yang tercemar oleh minyak. Stasiun 7-9 berada si daerah hilir yang telah menampung banyak pencemar toksik yang tidak dapat ditoleransi oleh lintah.

Cacing akuatik (Oligochaeta) yang ditemukan di S.Cisadane dari 2 suku yaitu Tubificidae dan Lumbriculidae. Branchiura sp. (Tubificidae) (Gambar 7a) dan Lumbriculus sp. (Lumbriculidae) (Gambar 7b) ditemukan sangat melimpah di Stasiun 7-9. Ketiga stasiun berdasarkan pengamatan memiliki kecepatan arus yang rendah dan berlumpur. Tubificidae dapat hidup di air sungai dengan bahan organik yang tinggi, keruh, berlumpur dan kandungan oksigen terlarut yang rendah. Mereka juga toleran terhadap pestisida namun kurang toleran terhadap ion logam berat (Brinkhurst \& Cook 1974). Kepadatan Branchiura dan Lumbriculus yang sangat tinggi di stasiun tersebut mengindikasikan adanya pencemaran organik.

$$
\text { Keanekaragaman }
$$

makrozoobenthos di S.Cisadane dapat menentukan tingkat kualitas air S.Cisadane. Secara umum, Indeks Keanekaragaman Hayati $\left(\mathrm{H}^{\prime}\right)$ semakin ke hilir semakin menurun. Indeks H' lebih tinggi di daerah hulu (S1,S2,S3) pada musim kemarau yaitu berturut-turut 3,$25 ; 2,78 ; 2,65$ (Tabel1). 


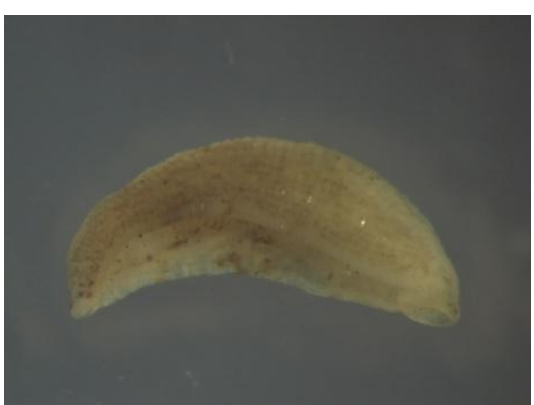

a. Helobdella sp.

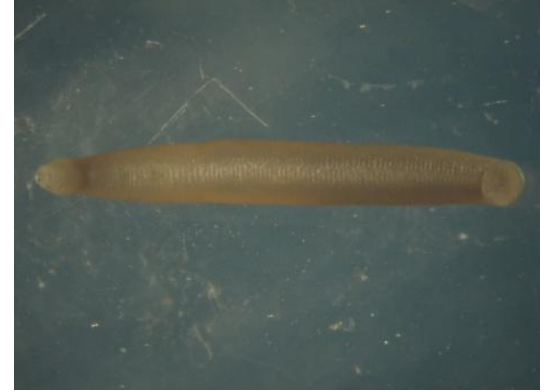

b. Glossiphonia sp.

Gambar 6. Makrozoobentos dari Taksa Hirudinea di S.Cisadane

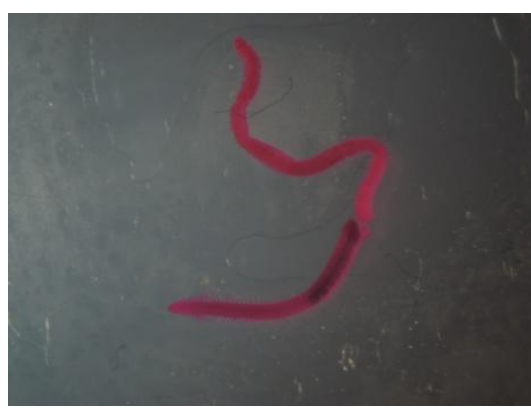

a. Branchiura sp. (Tubificidae) Gambar 7. Makrozoobentos dari Taksa Oligochaeta di S.Cisadane

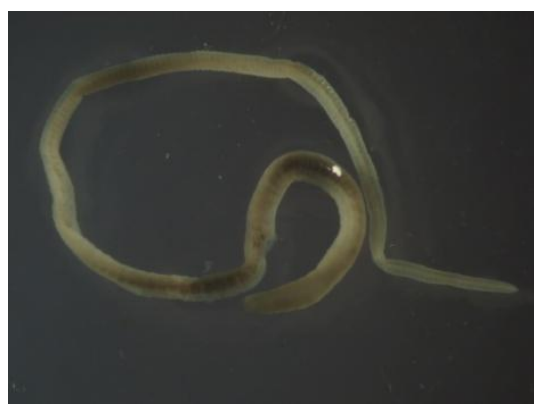

Indeks H' sedikit menurun di Stasiun 3 pada musim kemarau setelah air sungai memasuki Kota Bogor. Indeks $\mathrm{H}^{\prime}$ kemudian meningkat di Stasiun $4\left(H^{\prime}=2,90\right)$ dan Stasiun 5 $\left(H^{\prime}=2,82\right)$ yang berlokasi di Desa Gunung Sindur, Kabupaten Bogor. Indeks H' kemudian menurun lagi dari bagian tengah hingga hilir. Indeks $\mathrm{H}^{\prime}$ makrozoobentos pada musim hujan sangat berfluktuasi. Pengambilan sampel pada musim hujan yang menyebabkan kecepatan arus dan kekruhan air S.Cisadane berpengaruh terhadap kehadiran b. Lumbriculus sp. (Lumbriculidae) makrozoobentos. Secara umum, fluktuasi indeks $H^{\prime}$ seperti pada musim kemarau yaitu penurunan indeks H' ke arah hilir (Gambar 8). Indeks H' mengindikasikan bahwa kualitas air Sungai Cisadane semakin memburuk ke arah hilir akibat pencemar organik. Kualitas air S.Cisadane yaitu baik/tercemar sangat ringan di hulu (Stasiun 1), cukup baik/tercemar ringan (Stasiun 2-5), sedang/tercemar sedang (Stasiun 6), dan buruk/tercemar berat di hilir (Stasiun 7-9).

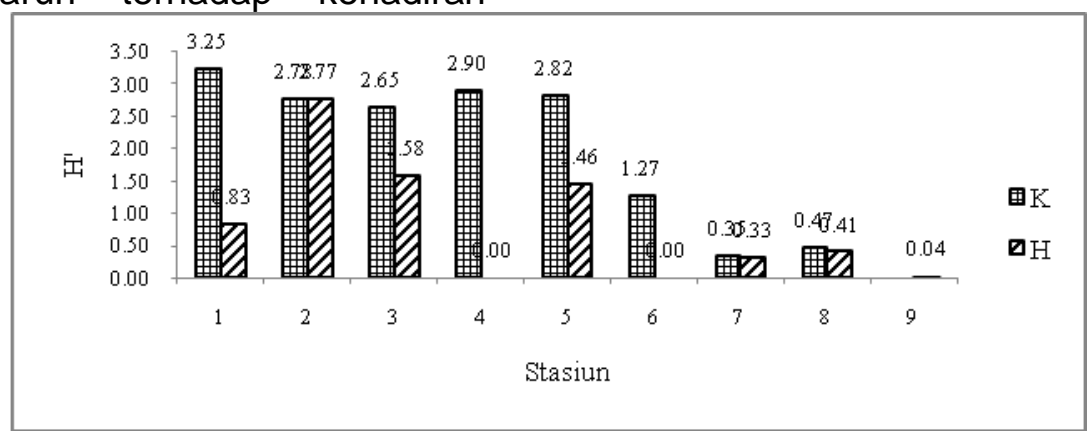

Gambar 8. Indeks keanekaragaman ( $\left.\mathrm{H}^{\prime}\right)$ makrozoobentos di S.Cisadane Keterangan: K:musim kemarau; $\mathrm{H}$ : musim hujan 
KESIMPULAN

Keanekaragaman

dan kekayaan taksa makrozoobentos dari hulu ke hilir semakin menurun namun banyaknya individu dari taksa tertentu meningkat. Indeks H' menunjukkan bahwa telah terjadi pencemaran sejak hulu hingga hilir. Kualitas air S.Cisadane yaitu baik/tercemar sangat ringan di hulu (Stasiun 1), cukup baik/tercemar ringan (Stasiun 2-5), sedang/tercemar sedang (Stasiun $6)$, dan buruk/tercemar berat di hilir (Stasiun 7-9).

\section{DAFTAR PUSTAKA}

Angelier E (2003) Ecology of streams and rivers.Science Publishers, Inc., Enfield \& Plymouth

Brinkhurst RO, Cook DG (1974) Aquatic earthworm (Annelida:Oligochaeta).

Dalam: Hart CW, Fuller SLH (eds) Pollution ecology of freshwater invertebrates.

Academic Press, Inc., London, pp 143-156

Covich AP, Palmer MA, Crowl TA (1999) The role of benthic invertebrate species in freshwater ecosystems. BioScience 49(2):119-127

Fachrul MF (2007) Metode Sampling Bioekologi. Bumi Aksara, Jakarta

Harman WN (1974) Snails (Mollusca:Gastropoda).

Dalam: Hart CW, Fuller SLH (eds) Pollution ecology of freshwater invertebrates. Academic Press, Inc., London, pp 275-312

Jutting WSSB van (1953). Critical Revision of the Freshwater Bivalves of Java in Systematic Studies on the Non-marine Mollusca of the Indo-Australian

Archipelago.Treubia. Vol. 22 Part 1. Museum Zoologicum Bogoriense, Bogor
Jutting WSSB van (1956). Critical Revision of the Freshwater Gastropods of Java in Systematic Studies on the Non-marine Mollusca of the Indo-Australian

Archipelago.Treubia. Vol. 23 Part 2. Museum Zoologicum Bogoriense, Bogor

Magurran AE (1991) Ecological diversity and its measurement. Chapman \& Hall, New York

Mason CF (1981) Biology of

Freshwater

Pollution.Longman, London \& New York.

Odum EP (1971) Fundamentals of Ecology, Edisi ke-3. W.B.Saunders Co., Philadelphia

Pennak RW (1953). Fresh-water Invertebrates of the United States. Edisi ke-2. John Wiley \& Sons, New York

Roback SS (1974) Insects (Arthropoda:Insecta) Dalam: Hart CW, Fuller SLH (eds) Pollution ecology of freshwater invertebrates. Academic Press, Inc., London, pp 313-376

Sawyer RT. 1974. Leeches (Annelida:Hirudinea). Dalam: Hart CW, Fuller SLH (eds) Pollution Ecology of Freshwater Invertebrates. Academic Press Inc., London, pp 81-142

Sudarso Y. 2002. Chironomidae sebagai indikator biologis perairan dan hama potensial. Warta Limnologi 35:4-10

Wilhm JL. 1975. Biological indicator of pollution. Dalam: Whitton BA (eds). River Ecology. Blackwell Scientific Publications, Oxford, pp 375402 
Tabel 1 Kepadatan, Kekayaan Taksa (S), dan Indeks Keanekaragaman (H') Makrozoobentos di S.Cisadane pada Kemarau dan Hujan 2011

\begin{tabular}{|c|c|c|c|c|c|c|c|c|c|c|c|c|c|c|c|c|c|c|c|}
\hline \multirow[t]{2}{*}{ Class/Ordo } & \multirow[t]{2}{*}{ Familia } & \multirow[t]{2}{*}{ Species } & \multicolumn{2}{|c|}{ S-1 } & \multicolumn{2}{|c|}{ S-2 } & \multicolumn{2}{|c|}{ S-3 } & \multicolumn{2}{|c|}{ S-4 } & \multicolumn{2}{|c|}{ S-5 } & \multicolumn{2}{|c|}{ S-6 } & \multicolumn{2}{|c|}{ S-7 } & \multicolumn{2}{|c|}{ S-8 } & S-9 \\
\hline & & & $\mathbf{K}$ & $\mathbf{H}$ & $\mathbf{K}$ & $\mathbf{H}$ & $\mathbf{K}$ & $\mathbf{H}$ & $\mathbf{K}$ & $\mathbf{H}$ & $\mathbf{K}$ & $\mathbf{H}$ & $\mathbf{K}$ & $\mathbf{H}$ & $\mathbf{K}$ & $\mathbf{H}$ & $\mathbf{K}$ & H & $\mathbf{H}$ \\
\hline Insect & Elmidae & Narpus sp. & 0 & 119 & 470 & 352 & 0 & 111 & 14 & 0 & 0 & 0 & 0 & 0 & 0 & 0 & 0 & 0 & 0 \\
\hline \multirow[t]{3}{*}{ Coleoptera } & Dytiscidae & Agabus sp. & 0 & 0 & 4 & 0 & 0 & 0 & 0 & 0 & 0 & 0 & 0 & 0 & 0 & 0 & 0 & 0 & 0 \\
\hline & Ptilodactylidae & Ptilodactylidae (Sp.1) & 15 & 0 & 4 & 4 & 0 & 0 & 0 & 0 & 0 & 0 & 0 & 0 & 0 & 0 & 0 & 0 & 0 \\
\hline & Gyrinidae & Dineutus sp. & 0 & 0 & 0 & 4 & 0 & 0 & 0 & 0 & 0 & 0 & 0 & 0 & 0 & 0 & 0 & 0 & 0 \\
\hline \multirow[t]{5}{*}{ Diptera } & Tipulidae & Antocha sp. & 37 & 0 & 41 & 4 & 0 & 0 & 0 & 0 & 0 & 0 & 0 & 0 & 0 & 0 & 0 & 0 & 0 \\
\hline & Chironomidae & Pentaneura sp. & 0 & 0 & 0 & 0 & 8 & 0 & 11 & 0 & 0 & 0 & 0 & 0 & 0 & 0 & 0 & 0 & 0 \\
\hline & Chironomidae & Cardiocladius sp. & 4 & 0 & 4 & 0 & 0 & 0 & 0 & 0 & 0 & 0 & 0 & 0 & 0 & 0 & 0 & 0 & 0 \\
\hline & Chironomidae & Tanytarsus sp. & 22 & 0 & 7 & 0 & 0 & 0 & 0 & 0 & 0 & 0 & 0 & 0 & 0 & 0 & 0 & 0 & 0 \\
\hline & Chironomidae & Polypedilum sp. & 19 & 0 & 15 & 0 & 75 & 4 & 125 & 0 & 6 & 0 & 0 & 0 & 0 & 0 & 0 & 0 & 0 \\
\hline \multirow[t]{6}{*}{ Ephemenoptera } & Baetidae & Baetis sp. & 0 & 0 & 52 & 48 & 93 & 156 & 52 & 0 & 9 & 4 & 0 & 0 & 0 & 0 & 0 & 0 & 0 \\
\hline & Siphlonuridae & Ameletus sp. & 0 & 0 & 4 & 100 & 3 & 44 & 6 & 0 & 0 & 0 & 0 & 0 & 0 & 0 & 0 & 0 & 0 \\
\hline & Leptophlebiidae & Paraleptophlebia sp. & 67 & 0 & 67 & 63 & 19 & 48 & 67 & 0 & 0 & 0 & 0 & 0 & 0 & 0 & 0 & 0 & 0 \\
\hline & Ephemerellidae & Ephemerella sp. & 0 & 4 & 22 & 11 & 0 & 0 & 0 & 0 & 0 & 0 & 0 & 0 & 0 & 0 & 0 & 0 & 0 \\
\hline & Heptagenidae & Heptagenia sp. & 0 & 0 & 0 & 0 & 0 & 0 & 3 & 0 & 0 & 0 & 0 & 0 & 0 & 0 & 0 & 0 & 0 \\
\hline & Neoephemeridae & Neoephemera sp. & 0 & 0 & 0 & 0 & 3 & 0 & 3 & 0 & 0 & 0 & 0 & 0 & 0 & 0 & 0 & 0 & 0 \\
\hline Hemiptera & Neocoridae & Pelocoris sp & 0 & 0 & 0 & 4 & 0 & 0 & 0 & 0 & 0 & 0 & 0 & 0 & 0 & 0 & 0 & 0 & 0 \\
\hline Lepidoptera & Pyralidae & Parapoynx sp. & 0 & 0 & 37 & 37 & 23 & 26 & 28 & 0 & 0 & 0 & 0 & 0 & 0 & 0 & 0 & 0 & 0 \\
\hline Plecoptera & Perlidae & Acroneuria sp. & 7 & 4 & 37 & 22 & 0 & 0 & 0 & 0 & 0 & 0 & 0 & 0 & 0 & 0 & 0 & 0 & 0 \\
\hline \multirow[t]{6}{*}{ Trichoptera } & Hydropsychidae & Cheumatopsyche sp. & 19 & 4 & 19 & 11 & 410 & 2122 & 333 & 0 & 22 & 0 & 0 & 0 & 0 & 0 & 0 & 0 & 0 \\
\hline & Hydropsychidae & Hydropsyche sp. & 11 & 7 & 30 & 52 & 0 & 7 & 0 & 0 & 0 & 0 & 0 & 0 & 0 & 0 & 0 & 0 & 0 \\
\hline & Hydropsychidae & Leptonema sp. & 0 & 0 & 4 & 0 & 0 & 0 & 17 & 0 & 0 & 0 & 0 & 0 & 0 & 0 & 0 & 0 & 0 \\
\hline & Polycentropodidae & Polycentropus sp. & 0 & 0 & 0 & 4 & 36 & 0 & 14 & 0 & 0 & 0 & 0 & 0 & 0 & 0 & 0 & 0 & 0 \\
\hline & Psychomyiidae & Psychomyiia sp. & 15 & 0 & 56 & 44 & 25 & 0 & 0 & 0 & 0 & 0 & 0 & 0 & 0 & 0 & 0 & 0 & 0 \\
\hline & Carydalidae & Carydalus sp. & 0 & 0 & 7 & 0 & 0 & 0 & 3 & 0 & 0 & 0 & 0 & 0 & 0 & 0 & 0 & 0 & 0 \\
\hline \multirow[t]{2}{*}{ Crustaceae } & Potamidae & Potamon sp. & 0 & 0 & 0 & 0 & 6 & 4 & 0 & 0 & 0 & 0 & 0 & 0 & 0 & 0 & 0 & 0 & 0 \\
\hline & Palaemonidae & Macrobrachium sp. & 0 & 0 & 0 & 0 & 4 & 0 & 2 & 0 & 0 & 4 & 7 & 0 & 0 & 0 & 0 & 0 & 0 \\
\hline
\end{tabular}


Tabel 1 Kepadatan, Kekayaan Taksa (S), dan Indeks Keanekaragaman (H') Makrozoobentos ...(lanjutan)

\begin{tabular}{|c|c|c|c|c|c|c|c|c|c|c|c|c|c|c|c|c|c|c|c|}
\hline \multirow[t]{2}{*}{ Class/Ordo } & \multirow[t]{2}{*}{ Familia } & \multirow[t]{2}{*}{ Species } & \multicolumn{2}{|c|}{$\mathrm{S}-1$} & \multicolumn{2}{|c|}{$\mathrm{S}-2$} & \multicolumn{2}{|c|}{$\mathrm{S}-3$} & \multicolumn{2}{|c|}{ S-4 } & \multicolumn{2}{|c|}{ S-5 } & \multicolumn{2}{|c|}{ S-6 } & \multicolumn{2}{|c|}{ S-7 } & \multicolumn{2}{|c|}{ S-8 } & S-9 \\
\hline & & & $\mathbf{K}$ & $\mathbf{H}$ & $\mathbf{K}$ & $\mathbf{H}$ & $\mathbf{K}$ & $\mathbf{H}$ & $\mathbf{K}$ & $\mathbf{H}$ & $\mathbf{K}$ & $\mathbf{H}$ & $\mathbf{K}$ & $\mathbf{H}$ & $\mathbf{K}$ & $\mathbf{H}$ & $\mathbf{K}$ & $\mathbf{H}$ & $\mathbf{H}$ \\
\hline \multirow[t]{8}{*}{ Gastropoda } & Thiaridae & Thiara sp. & 0 & 0 & 0 & 0 & 0 & 0 & 0 & 0 & 11 & 0 & 7 & 0 & 74 & 59 & 141 & 89 & 0 \\
\hline & Thiaridae & Melanoides sp. & 11 & 0 & 0 & 7 & 3 & 15 & 64 & 6 & 52 & 133 & 207 & 26 & 593 & 704 & 1170 & 815 & 33 \\
\hline & Thiaridae & Brotia sp. & 0 & 0 & 0 & 0 & 0 & 0 & 0 & 0 & 0 & 11 & 7 & 0 & 7 & 7 & 15 & 7 & 0 \\
\hline & Physidae & Physa sp. & 0 & 0 & 0 & 0 & 3 & 0 & 0 & 0 & 0 & 0 & 11 & 0 & 7 & 7 & 37 & 22 & 0 \\
\hline & Vivipandae & Bellamya sp. & 0 & 0 & 0 & 0 & 0 & 0 & 0 & 0 & 0 & 0 & 0 & 0 & 15 & 0 & 30 & 22 & 0 \\
\hline & Buccinidae & Anentome sp. & 0 & 0 & 0 & 0 & 0 & 0 & 0 & 0 & 0 & 0 & 0 & 0 & 7 & 0 & 7 & 7 & 0 \\
\hline & Neritidae & Septaria sp. & 0 & 0 & 0 & 0 & 0 & 0 & 3 & 0 & 0 & 0 & 0 & 0 & 0 & 0 & 0 & 0 & 0 \\
\hline & Ampularidae & Pomacea sp. & 0 & 0 & 0 & 0 & 0 & 0 & 0 & 0 & 0 & 0 & 0 & 0 & 0 & 0 & 0 & 0 & 22 \\
\hline Pelecypoda & Corbiculidae & Corbicula sp. & 0 & 0 & 0 & 0 & 0 & 0 & 0 & 0 & 0 & 11 & 0 & 0 & 0 & 0 & 7 & 0 & 0 \\
\hline Turbelaria & Planaridae & Cura sp. & 0 & 0 & 4 & 0 & 0 & 0 & 0 & 0 & 0 & 0 & 0 & 0 & 0 & 0 & 0 & 0 & 0 \\
\hline \multirow[t]{2}{*}{ Oligochaeta } & Tubificidae & Branchiura sp. & 7 & 0 & 0 & 0 & 6 & 0 & 2 & 0 & 7 & 0 & 0 & 0 & 44 & 30 & 74 & 59 & 89 \\
\hline & Lumbriculidae & Lumbriculus sp. & 63 & 0 & 22 & 4 & 5 & 4 & 6 & 0 & 11 & 0 & 7 & 0 & 13630 & 15037 & 18556 & 15519 & 16478 \\
\hline \multirow[t]{2}{*}{ Hirudinae } & Glossiphonidae & Helobdella sp. & 0 & 0 & 0 & 0 & 31 & 159 & 19 & 0 & 17 & 4 & 7 & 0 & 0 & 0 & 0 & 0 & 0 \\
\hline & & Glossiphonia sp. & 0 & 0 & 0 & 0 & 88 & 196 & 46 & 0 & 17 & 15 & 4 & 0 & 0 & 0 & 0 & 0 & 0 \\
\hline $\mathrm{N}$ & & & 296 & 137 & 904 & 770 & 840 & 2896 & 815 & 6 & 152 & 181 & 259 & 26 & 14378 & 15844 & 20037 & 16541 & 16622 \\
\hline S & & & 13 & 5 & 20 & 17 & 18 & 13 & 19 & 1 & 9 & 7 & 8 & 1 & 8 & 6 & 9 & 8 & 3 \\
\hline $\mathrm{H}^{\prime}$ & & & 3.25 & 0.83 & 2.78 & 2.77 & 2.65 & 1.58 & 2.90 & 0.00 & 2.82 & 1.46 & 1.27 & 0.00 & 0.35 & 0.33 & 0.47 & 0.41 & 0.04 \\
\hline
\end{tabular}

